\title{
Queer Youth and the Culture Wars: From Classroom to Courtroom in Australia, Canada and the United States
}

\author{
ELIZABETH J. MEYER \\ DAVID STADER
}

\begin{abstract}
This article builds on Lugg's (2006) discussion of surveillance in public schools and how queer youth are resisting schools' current efforts to regulate sexual orientation and gender expression in the U.S. and internationally. Legal complaints initiated by queer youth against their schools for harassment and access to extra-curricular activities are discussed. The number of cases in the past five years has increased significantly and the courts are siding with the youth and their allies, demonstrating that queer youth are significantly impacting the dismantling of heteronormative regulatory regimes and improving the school experiences for themselves and queer adults.
\end{abstract}

Queer (lesbian, gay, bisexual, transgender, or LGBT) youth are challenging the heteronormative cultures in schools as they disclose their sexual orientation at a younger age and with unprecedented regularity (Cloud, 2005; Janofsky, 2005). As the dominant values of these traditionally heteronormative institutions are questioned, schools have become important battlegrounds in the culture wars. Opponents of homosexuality, who have labored to ban same-sex marriage, also promote a heterosexual-based abstinence-only sex education curriculum in schools and thwart local school efforts to promote diversity education and safer school climates. School administrators and teachers, as gender and sexuality police, are expected to enforce conformity to heterosexual gender norms for the students (Lugg, 2006).

Many queer youth face discrimination, rejection, and hostility from peers, teachers, and administrators. We use the term "queer youth" to include not only LGBTidentified youth, but also those who are questioning their sexual orientation or gender identity, children of LGBT parents, and heterosexual youth who have been targeted with homophobic harassment in schools or identify as LGBT allies.

Introducing the reader to the legal battles with schools that have been led by queer youth in the U.S. and internationally, we examine how they and their allies have challenged and transformed homophobic school environments through legal complaints. We also discuss how the decisions of these court cases have resulted in changes to school policies, teacher training, curricular materials, and extra-curricular activities that will have long-term impacts.

We first present a brief overview of the challenges that many youth experience as a result of homophobia in schools and then discuss cases from the United States along with their main legal arguments: Equal Protection, Title IX, the Equal Access Act and state non-discrimination laws. In the third section we present three cases from Canada and Australia; and finally we discuss the significance of these cases for queer youth in schools. 


\section{SCHOOL CULTURE: CHALLENGES FOR YOUTH}

Queer youth face many of the same challenges as all youth. Like all teens, these youth seek a school culture characterized by caring teachers and administrators, positive peer relationships, and a safe and orderly school environment (Elze, 2003; Illingworth \& Murphy, 2004; Savin-Williams, 2001; Weiler, 2003). However, for at least some youth these years are filled, not with hope and promise, but with verbal abuse and harassment from peers and rejection by teachers and administrators because of their real or perceived sexual orientation and/or their gender identity and/or expression. The research on the relative frequency and impact of peer harassment and rejection by teachers is sobering.

Peer Harassment

A 2005 survey of 3450 students aged 13-18 in the United States by The Gay, Lesbian and Straight Education Network found:

- 33 percent of the respondents report that students in their school are frequently harassed because of their real or perceived sexual orientation;

- 52 percent hear students make homophobic remarks very often or often;

- 36 percent reported bullying or name calling based on sexual orientation to be a very or somewhat serious problem at their school; and

- 90 percent of LGBT teens have been verbally or physically harassed or assaulted during the past year because of their perceived or actual appearance, gender, sexual orientation, gender expression, race/ethnicity, disability or religion. (Harris Interactive \& GLSEN 2005, 7)

In a study of secondary school educational leadership candidates' perceptions of school culture and sexual minority youth, Stader and Graca (2006) found that 62 participants $(74 \%)$ indicated that they had witnessed student-on-student harassment based on real or perceived sexual orientation on their campus. In this same study, 30 percent of the participants reported that either a student or a parent had complained to them personally on at least one occasion regarding sexual harassment based on real or perceived sexual orientation. However, in 2008, GLSEN reported that only one-in-five school principals report that their school engaged in efforts to create a safe environment for LGBT students (Greytak \& Kosciw, 2008).

\section{Intolerance of Faculty and Administrators}

Teachers and administrators play an important part in the lives of teens. This may be particularly true for queer youth. For example, Elze (2003) found that although LGB youth rated having heterosexual peer support as most important in promoting a positive school experience, this was followed very closely by having teachers who care about them. In another study, the Human Rights Watch found in virtually every 
case where queer students reported a positive school experience they attributed it to supportive teachers (Bochenek \& Brown, 2001, 96). Moreover, in another study (Kosciw, 2004, 23-24), the average grade point average (GPA) of sexual minority students who could not identify any supportive faculty was 2.8 . The average GPA of participants who could identify supportive faculty was 3.1. Finally, these students were more than twice as likely (24\% as compared to $10 \%)$ to plan to attend college.

Queer students describe supportive teachers as those who: confront homophobic name calling, post queer-positive brochures and posters in their classrooms, incorporate GLBT content in the curriculum, and/or act as faculty advisors to student-led gay-straight alliances (Bochenek \& Brown, 2001; Kosciw \& Diaz, 2006; Lipkin, 1999; MacGillivray, 2007; Perrotti \& Westheimer, 2001).

However, queer youth report rejection by teachers and school administrators in some schools. Additionally, Stader and Graca (2006) found that approximately one-fourth of educational leadership candidates in the Dallas-Fort Worth area reported being uncomfortable providing academic support for sexual-minority students and one-third reported being uncomfortable providing emotional support to these students. This lack of comfort may contribute to homophobic comments (queer youth have reported teachers often telling homophobic jokes in class; Elze, 2003) and/or rejection, and is often connected to personal religious beliefs. For example, Thomas McLaughlin won a settlement of $\$ 25,000$ with his middle school in Little Rock, Arkansas, after being told by at least two teachers that homosexuality is a sin and forced to read the Bible by an administrator (McLaughlin v. Pulaski County Special School District, 2003).

Through persistent violence, discrimination, and exclusion, school authorities police gender and sexual identities and behaviors. As queer legal scholar Catherine Lugg (2006) points out, the institution of the school acts much like a prison to regulate gender and sexuality through constant surveillance by teachers and peers alike. Enforcement often takes the form of anti-gay jokes, gendered insults, shunning, and other forms of harassment that force queer youth to try and act "heterosexual" in order to remain safe.

This policing is not limited to the U.S. Research and news reports from Australia (Martino \& Pallotta-Chiarolli, 2003; Mills, 2006; Thonemann, 1999), New Zealand (OutThere, New Zealand AIDS Foundation, \& Rainbow Youth, 2004), the United Kingdom (Forrest, 2000; Phoenix, Frosh, \& Pattman, 2003; Warwick, Goodrich, Aggleton, \& Chase, 2006), Canada (Meyer, 2007; Smith \& Smith, 1998; Williams, Connolly, Pepler, \& Craig, 2003), the Netherlands (Timmerman, 2003), and South Africa (Barnes, 2006) report similar, if not more severe, problems for queer youth in schools. However, youth in these countries have not turned to the courts with as much frequency as U.S. students.

\section{LEGAL PROTECTIONS AND CASE LAW}

Queer youth have taken to the courts to defend their rights to full and equal access to an education. There are, however, significantly fewer cases outside of the United States.

In Canada, rights for queer youth are broadly protected by Federal and Provincial Human Rights Codes. These rights have been firmly established since 1995 when "sexual orientation" was read into the Canadian Charter of Rights and Freedoms as a protected class as a result of a landmark decision by the Supreme Court of Canada (Egan v. Canada, 1995). This is a major difference between the federal legal regimes in the U.S. and Canada. 
In 2002, Azmi Jubran won his case against his school board in British Columbia for a harassment complaint. Jubran does not identify as gay, but he was subjected to years of bullying and harassment and anti-gay epithets were used regularly against him. He initiated a human rights complaint against his school in June 1996, and in April 2002 the Human Rights Tribunal of British Columbia found in his favor and awarded him $\$ 4,500$ in damages. This decision was overturned by the Supreme Court of British Columbia on the grounds that Jubran did not identify as homosexual and, therefore, should not be protected by the human rights codes. The British Columbia Court of Appeals heard the case and reinstated the earlier decision. In 2005, the Supreme Court of Canada refused to hear the appeal which established a precedent for students and educators across Canada (School District No. 44 v. Jubran, 2005). ${ }^{1}$

Another case in which school authorities failed to protect a student who was subjected to persistent and repeated homophobic harassment was in Australia. ${ }^{2}$ Christopher Tsakalos was a 14-year-old student at Cranebrook High School, a Syndney suburb. With the support of his mother, he filed a complaint against his school for breaching their "duty of care" for failing to act effectively to stop the anti-gay harassment he was experiencing (Staff, 1997). The courts sided with Tsakalos. Following this April 1997 decision, the Director General of the New South Wales (NSW) Department of Education and Training (DET) issued a memorandum to schools that October, reminding them of the materials available to teach against homophobia.

Additionally, the DET informed schools that they would gather information on, "the incidence of homophobia in secondary and central schools with the intention of identifying any gaps in terms of the provision of resource materials and teaching and learning" (Thonemann, 1999, p. 2) as well as provide anti-homophobia training to faculty and students in the school to which Christopher was transferred (Staff, 1997).

In the United States, LGBT people are not specifically protected from discrimination based on their sexuality or gender identity/expression at the federal level since they are not legally considered a suspect or quasi-suspect class. Nevertheless, a significant number of courts across the country have begun holding school districts liable for their failure to adequately address student-on-student harassment and bullying based on real or perceived sexual orientation and/or gender identity and expression. Without explicit federal protections, the success of these cases depends on the courts and the effectiveness of the lawyerly arguments based on existing protections, generally: Equal Protection, Title IX, state non-discrimination laws and The Equal Access Act.

\section{Equal Protection}

The Equal Protection Clause of the 14th Amendment guarantees equal application of a law to all people in the United States (U.S. Constitution, Amendment XIV, s. 1). An equal protection claim thus requires the student to show that school officials a) did not fairly and consistently apply policies when dealing with the student, b) were deliberately indifferent to the student's complaints, or that the student was treated in a manner that is c) clearly unreasonable (Stader, 2007).

The first example of this argument being successfully applied to homophobic harassment in schools was in the case Nabozny v. Podlesny (1996). Jamie Nabozny was subjected to violent and persistent anti-gay harassment over several years in his Wisconsin school. As a result he had been hospitalized, dropped out of school, and attempted suicide (Lipkin, 1999). Ruling in favor of Nabozny, the federal appeals 
judges wrote that "we are unable to garner any rational basis for permitting one student to assault another based on the victim's sexual orientation ... "; the school district settled with Nabozny for $\$ 900,000$ (Nabozny v. Podlesny, 1996, p. 11). Another important outcome of this case was that, since the school board already had policies prohibiting this sort of harassment, three administrators were held personally liable and would have been financially responsible for the damages had the school district not offered a settlement upon hearing the court's decision (Bucket, 2000).

Two other recent examples of the Equal Protection argument in such cases include Flores v. Morgan Hill (2003) and Nguon v. Wolf (2007). In Flores, the Federal 9th Circuit Court of Appeals found ample evidence of deliberate indifference to the ongoing sexual orientation harassment of six students in this California School District which resulted in a 1.1 million dollar settlement with the students (ACLU, 2004) and the requirement that the school district implement a training and education program for its administrators, faculty, and students (Dignan, 2004).

In Nguon, the plaintiff, Ms. Nguon, alleged that she had been suspended for expressing affection towards her girlfriend whereas similar behaviors by heterosexual couples were ignored. She was also outed to her family as part of the disciplinary procedures, which, she alleged, violated her privacy rights under California and U.S. Constitutional law. In cases where a student is facing suspension, school administrators are required by federal and state law to provide rudimentary procedural due process before suspending a student. The student has the right to know what rule has been broken and parents must be informed of the reason for the suspension (Goss v. Lopez, 1975). Although the principal was legally within his rights to notify the family that the student was being suspended for "inappropriate public displays of affection (IPDAs)" (Nguon v. Wolf, 2007 p. 7), it was not necessary to specify that these IPDAs were conducted with another female student. In fact, the principal exposed her potentially to increased anxiety, distress, physical and mental abuse, and homelessness by disclosing this information to her mother (D'Augelli, 2002; Fedders, 2006).

In this case, the Central California District Court held that the school did not violate Nguon's rights to equal protection, privacy, and free speech (Nguon v. Wolf, 2007). Nguon and her lawyers plan to appeal (Staff, 2007).

\section{Title IX}

In addition to Equal Protection arguments, queer youth have been successful in using Title IX of the Educational Amendments of 1972 to challenge, at the federal level, the harassment they were experiencing in schools.

Title IX provides statutory protection for student-on-student sexual harassment under the following conditions: a) school personnel have actual knowledge of the harassment; b) school officials demonstrate deliberate indifference or take actions that are clearly unreasonable; and c) the harassment is so severe, pervasive, and objectively offensive that it can be said to deprive the victim(s) of access to the educational opportunities or benefits provided by the school (Davis v. Monroe, 1999, par. 1).

Several attorneys have successfully argued that Title IX protects students from peer sexual orientation harassment. A California Federal District Court concurred, finding

no material difference between the instance in which a female student is subject to unwelcome sexual comments and advances due to her harasser's perception that she is 
a sex object, and the instance in which a male student is insulted and abused due to his harasser's perception that he is a homosexual, and therefore a subject of prey. In both instances, the conduct is a heinous response to the harasser's perception of the victim's sexuality, and is not distinguishable to this court. (Ray v. Antioch Unified School District, 2000, 1170)

In 2000, two important cases were decided that applied Title IX to incidences of homophobic harassment: Ray v. Antioch Unified School District (2000), and Montgomery v. Independent School District No. 709 (2000). In both cases, separate federal district courts (California and Minnesota, respectively) decided that schools could be held liable under Title IX for acting with "deliberate indifference" towards students who have reported persistent and severe homophobic harassment at school. These decisions established important precedents for the cases that followed.

In Henkle v. Gregory (2001), a student's complaint led to far-reaching changes in his school district. The federal district court of Nevada allowed the Title IX sexual orientation harassment case of Derek Henkle for punitive damages to proceed. The ensuing settlement awarded $\$ 451,000$ in damages to the student and led to several district policy changes that extend existing protections for free speech and discrimination and harassment to include sexual orientation and gender expression (Lambda Legal, 2001).

A few years later a Kansas federal district court considered gender stereotyping, and the related anti-gay harassment of a student who did not identify as gay, actionable under Title IX (Theno v. Tonganoxie, 2005). The court wrote that "the plaintiff was harassed because he failed to satisfy his peers' stereotyped expectations for his gender because the primary objective of plaintiff's harassers appears to have been to disparage his perceived lack of masculinity" (p. 952). Therefore the court concluded that the harassment of Dylan Theno was so, "severe, pervasive, and objectively offensive that it effectively denied (him) an education in the Tonganoxie school district" (p. 966). The district settled with Dylan for a total of \$440,000 (Trowbridge, 2005).

One case, however, had a very different outcome. In Doe v. Bellefonte School District (2004), the court decided for the school district. Because campus administrators took Doe's complaints seriously, instituted a series of steps in response to complaints, and escalated punishment when necessary, the court ruled the district was not deliberately indifferent to Doe's harassment. Thus when school officials take appropriate steps to respond to complaints of harassment, they may not only ensure the safety of all students but also avoid costly and time-consuming legal battles.

\section{State and Local Non-Discrimination Laws}

State non-discrimination laws that protect individuals based on sexual orientation and/or gender identity exist in only 20 states and the District of Columbia ${ }^{3}$ (National Gay and Lesbian Task Force, 2007). However, according to a 2008 study, only 11 states $^{4}$ and the District of Columbia (California, Connecticut, Iowa, Maine, Maryland, Massachusetts, Minnesota, New Jersey, Vermont, Washington, and Wisconsin) have statutes specifically protecting students in schools from discrimination on the basis of sexual orientation and/or gender identity (Kosciw \& Diaz, 2008). Students in these states also reported significantly lower rates of verbal harassment than their peers vis a-vis those from states absent such statutes. Since this report, several states, have considered bills either expanding or limiting the rights of sexual minority students 
(Buchanan, 2006). Already seven states have legislation that prohibits the positive portrayal of homosexuality (Alabama, Arizona, Mississippi, Oklahoma, South Carolina, Texas, and Utah); students in these states reported being verbally harassed at a higher frequency than students from states without such legislation $(47.6 \%$ as compared to 37.2\%; Kosciw \& Diaz, 2006).

Two cases that were brought before state courts are worth noting in this context. A Massachusetts case, Doe v. Yunits (2000) is the only case that addresses transgender youth in schools. "Pat Doe," a 15-year-old trans-gender eighth grader, won the right to attend school wearing clothing that expresses her female gender identity. Her principal regularly had sent her home to change her attire and began requiring her to check with him to have her clothing approved on a daily basis. It was found that such treatment violated sex discrimination protections provided by the Commonwealth of Massachusetts and that the school could not place restrictions on her attire based on her sex assigned at birth. The Appeals Court supported the lower court's decision to issue an injunction requiring the school to permit Pat to attend, "in clothing and accessories that express her female gender identity" (Doe v. Yunits, 2000, p. 2).

New Jersey extended the protections offered by state anti-discrimination laws to cover students in schools as a result of the suit brought by a student who had suffered persistent homophobic harassment. The New Jersey Supreme Court held that schools may be held liable under the state Law Against Discrimination for permitting studenton-student bias-based harassment (American Civil Liberties Union-New Jersey, 2007). "[R]easonable measures are required to protect our youth, a duty that schools are more than capable of performing," wrote Chief Justice Zazzali. "[W]e require school districts to implement effective preventive and remedial measures to curb severe or pervasive discriminatory mistreatment" (L. W. v. Toms River Regional Schools Board of Education, 2007, p. 27-29). The requirement that schools take preventive and remedial measures could have far-reaching impacts in schools across New Jersey.

These cases exemplify how the activism of youth, with the support of family and community, will likely have a significant long-term impact on transforming the climate in schools. The Marc Hall prom date case, discussed later in this article, is one example of a student who had the support of his parents, friends, and community activists as he pursued his legal complaint against the school. It is clear that the emotional, financial, and political support of these groups made it possible for Marc Hall to challenge the homophobic policy of his Catholic School through official letters of complaint, meetings with lawyers, talking with the press, and working with community activists (Grace \& Wells, 2005).

The difference between a positive and a toxic school experience for queer youth is not a secret and the courts have sided with the youth in many of these cases. Therefore, it is incumbent upon school districts to take affirmative steps to provide a positive, supportive, and safer school culture for all students, rather than waiting for a youth activist to seek court intervention. This assumption, however, is not without controversy.

Gay-Straight Alliances (GSAs) and the Equal Access Act

Peer support groups, commonly known as gay-straight alliances (GSAs), have become increasingly common in schools (Cloud, 2005; Fischer \& Kosciw, 2006). Limited research is available on the efficacy of GSAs, but in recent years there has been a growing body 
of research that has investigated the impact of GSAs on school climate (Fischer \& Kosciw, 2006; Griffin, Lee, Waugh, \& Beyer, 2004; Kosciw \& Diaz, 2006; Mayo, 2004; Szlacha, 2001; 2003) as well as the experiences of students who have been involved in such organizations (Bochenek \& Brown, 2001; Garcia-Alonso, 2004; GLSEN \& Harris Interactive, 2005; Goodenow, Szlacha, \& Westheimer, 2006; Mayo, 2004; Macgillivray, 2004; 2007; Sampson, 2000). These studies indicate that schools with GSAs are more welcoming of all kinds of diversity, including racial, ethnic, and religious as well as gender and sexual orientation. In these schools LGBT students and family members feel safer and experience a greater sense of belonging. Fischer and Kosciw (2006) found that the presence of a GSA directly predicted greater school belonging and indirectly predicted greater academic achievement for sexual-minority youth. In Szlacha's (2003) evaluation of the Massachusetts Safe Schools Program, the presence of a GSA was the aspect "most strongly associated with positive sexual diversity climates" (p. 73).

Nevertheless, GSAs are not always met with open-mindedness from students, teachers, administrators, parents, community members, and school boards.

For example, controversy including a student walk-out, "open hostility" from opponents, an acrimonious school board meeting, and a protest from local ministers followed when a student-initiated GSA petitioned the Boyd County High School (Canonsburg, Kentucky) to meet during non-instructional time. In an effort to put an end to the problems surrounding the GSA, the principal proposed to ban all noncurricular clubs. However, several non-curricular clubs including the Drama Club and a Bible Club continued to meet during non-instructional time and home room. The GSA petitioned the courts for the same access as other non-curricular groups (Boyd County High School Gay Straight Alliance v. Board of Education of Boyd County, 2003). The Federal district court determined that Boyd County High School continued to operate a "limited open forum" and that denying the GSA the same opportunities violated the Equal Access Act (EAA).

The Federal district court also considered the uproar surrounding the GSA. It acknowledged that schools could ban groups that created "material and substantial disruption" to the educational process (Tinker v. Des Moines, 1969). However, in this case, the disruption was caused by GSA opponents, not GSA members. The court interpreted Tinker and the "heckler's veto concept" (Terminiello v. Chicago, 1949) as designed to prevent school officials from punishing students for freely expressing unpopular views, instead of punishing the students who respond to the views in a disruptive manner.

Other courts have reached similar conclusions that school districts have violated the EAA when banning GSA groups because of student, parent, and/or community protests while continuing to operate a limited open forum. Straights and Gays for Equity v. Osseo Area Schools (2006), reaffirmed in 2008, and White County High School Peers Rising in Diverse Education v. White County School District (2006) serve as two recent examples from other Federal District Courts (Minnesota and Georgia, respectively).

On the other hand, a Texas Federal District court sided with the school's decision to ban the GSA in Caudillo v. Lubbock (2004). This case differs from the above cases in at least one significant way: The GSA allied itself with an outside advocate whose website linked information about safer sex practices. The school and the court viewed this information as "sexually explicit" and "obscene." Due to existing school policies that endorsed abstinence-only education and the state sodomy law, which, ironically, had recently been ruled unconstitutional (see Lawrence v. Texas, 2003), the court sided 
with the school's decision to ban the GSA-even though the students removed the link to the website (Leonard, 2004).

Some state legislators have introduced legislation to prohibit GSAs or, at a minimum, to require parental permission for student participation in such organizations. Idaho, Utah, Virginia, Tennessee, and Georgia have attempted to block or discourage GSA-type groups. As of this writing, Utah and Georgia are the only states that have successfully passed parental-permission legislation (Bagby, 2006; Toomer-Cook, 2007). However, some local school districts in Florida, North Carolina, and Texas have also implemented such policies following the creation of a GSA (ACLU, 2007; NCSSE, 2003; Staff, 2006). State laws are unnecessary, as school boards already have the authority to include parents and community members in decisions about clubs and school activities. Such laws also may interfere with local governance and could create new and expensive bureaucratic requirements for any new club. Most importantly, such laws could unnecessarily expose students to harm if their involvement in a GSA is revealed to a non-supportive parent or guardian.

Efforts to derail GSAs at the community level are common. For example, the Rowan-Salisbury (North Carolina) School Board denied permission for a GSA club after more than 100 spectators voiced opposition (Lyttle, 2006). The North Idaho Pachyderm Club invited a local principal and GS A advisors to their meeting to express their concern over a local high school support group. Amid threats to block school levies until the club was disbanded, the group expressed concerns over pedophilia and the "promotion of an immoral and detrimental lifestyle" (Madkor, 2006, n.p.). Lake City High (Coeur d'Alene, Idaho) has an active GSA (Lake City High School Clubs, 2008).

In spite of such community opposition, the Equal Access Act is clear and most school districts have decided to allow these groups to meet. In a 2003 Texas case, Klein School District officials said that they would have fought the lawsuit brought by the GSA and ACLU if they thought they had a chance of winning the case. The superintendent stated: "The issue is that regardless of my personal feelings, the principal's personal feelings or the community's opinion it is a matter of law" (NCSSE, 2003, n.p.). When this decision was announced, a student from this GSA commented, "I definitely think that the effort was worth it. I had to give up a little bit of time, but now my school is going to be a whole lot safer because of it. "(NCSSE, 2003, n.p.). Due to the commitment and courage of the students who work to initiate these GSAs, there are now over 3,000 such groups in schools and at least one in every state in the United States (Macgillivray, 2007).

In Canada, the growth of GSAs has been slower. One group at an Ontario school has been trying for several years to start a GSA, but community resistance has kept it from being established (Dokladalova, 2007). In another instance, an Ontario school board paid a $\$ 5,000$ settlement after a student filed a human rights complaint when his school refused his request to start a GSA (Moran, 2006). His school never apologized and still has no official GSA (Dias, 2008). Since there is no central network for GSAs in Canada, estimated numbers vary. There are currently 44 GSAs listed on the Gay and Lesbian Educators in British Columbia website (www.galebc.org/gsa) and others documented in Alberta, Saskatchewan, Manitoba, Ontario, Quebec, and Nova Scotia.

There are a few GSAs established in the UK that have a presence on the web (http://pks-no-outsiders.blogspot.com/) and there is one documented GSA in Mexico (MacGillivray, 2005). No firm data are available for Australia. 
It may not be uncommon for two or more young women or men to attend school homecoming and prom activities as same-sex friends. However, when the young women or men plan to attend as a couple, attitudes sometimes change. In an early example, no one was concerned about Aaron Fricke's date to a senior reception and dance until he sought permission to bring a male date (Fricke v. Lynch, 1980). Aaron's principal denied permission based, in part, on fears of physical harm to Aaron and his companion and concerns from the community. Fricke brought a complaint against his school alleging that this denial limited his first amendment rights to freedom of expression and association. Justice Pettine did not accept the school district's "heckler's veto" argument that the potential for violence and the safety of others at the prom superseded Fricke's first amendment rights. The court concluded that "The first amendment does not tolerate mob rule by unruly school children" (Fricke v. Lynch, 1980, p. 387).

Two decades following Justice Pettine's conclusion, same-sex couples attending school dances remains controversial (Ravitz, 2004a, 2004b). As recently as 2006, a principal of Denham Springs High School in Louisiana announced that such couples would not be allowed to attend the prom. A student from the school contacted the ACLU and the principal responded to a letter from the ACLU of Louisiana by publicly announcing that same-sex couples would be welcome at the prom (ACLU, 2007).

In a widely-publicized Canadian case, Marc Hall, an Ontario teen attending a publicly-funded Catholic school, sought permission to bring a same-sex date to his prom in 2002. His school refused and Hall successfully obtained a temporary injunction from the Ontario Court of Justice (Grace \& Wells, 2005; Hall v. Durham Catholic District School Board, 2005). The judge hearing the request wrote, "exclusion of a student from a significant occasion of school life, like the school prom, constitutes a restriction in access to a fundamental social institution" (Mackinnon, 2002, par. 1). Although it provided a valuable opportunity to examine the competing constitutional rights of religious freedom and non-discrimination in public institutions, this case did not continue to a full hearing. In obtaining the temporary injunction, Marc achieved his goal of bringing his boyfriend to prom and later dropped the complaint against his school and school board.

\section{IMPLICATIONS}

It is well documented that queer youth are particularly at-risk of being victimized by peers, of being rejected by teachers and administrators, of dropping out of school, and having higher rates of suicide ideation than their heterosexual peers (Bochenek \& Brown, 2001; California Safe Schools Coalition, 2004; D'Augelli \& Hershberger, 1993; Dorais \& Lajeunesse, 2004; Fisher, 1999; Kosciw \& Diaz, 2006; Lock, 2002; Thompson \& Johnson, 2003). In the face of all of these risk factors, many youth have shown incredible resiliency. Queer youth and their allies have played an important role in challenging the regulatory regimes in their schools and communities.

As other writers have pointed out, taking legal action against one's school district, "requires an immense amount of courage and awareness, not something that most middle and high school students have in abundance" (Dignan, 2004, par. 20). Fortunately, there have been a few brave teens who have worked with advocacy 
groups, supportive family members, and community groups to defend their rights through legal action against their schools. Since the early cases of Fricke v. Lynch (1980) and Nabozny v. Podlesny (1997) there has been a steady increase in the numbers of youth bringing their complaints to the courts, particularly in the United States (Bochenek \& Brown, 2001; Eisemann, 2000; Lugg, 2003; Lipkin, 1999; Stader \& Meyer, 2006). This increase may indicate that youth (and their families) are feeling more confident and supported in pursuing such cases due to greater visibility of queer role models, availability of information, and support and advocacy. Moreover, the winning record of queer youth in the courts presages continued gains in the culture wars.

Administrators and school boards could avoid the controversy, the costs, and the negative public relations generated by these culture wars, if not the lawsuits themselves, by responding proactively to student complaints. They could create safer and more inclusive schools by educating their teachers and principals of their legal and professional responsibilities in working with queer youth.

In addition to the financial and other burdens created by pursuing legal action, these public battles can often polarize communities and generate more hostility towards targeted students. Queer youth have often had to fight for many years to get schools to do the right thing: update policies, provide new professional development workshops, and add more inclusive curricular materials to course work, and in the school library-the most common changes schools have been required to make in addition to financial penalties (ACLU, 2004).

Consequently, schools of education must also work harder to prepare teachers and administrators to address these issues. Teacher education programs can provide new teachers with important opportunities to explore bias-related issues in courses on multicultural education and explicitly address gender and sexual diversity issues. They can offer future teachers examples of inclusive curricular materials, models for talking about harassment related to gender and sexual orientation, as well as sample class activities that allow students to practice addressing and challenging incidents of homophobia, transphobia and harassment. Providing student teachers a safe environment in which to practice having these discussions and experience a model of an antioppressive classroom is important so that they can develop confidence in their abilities to effectively address bias and teach inclusively (Meyer, 2006; Meyer, 2008a).

Educational leadership programs and coursework must also present legal, ethical, and anti-oppressive approaches to school leadership. Programs should explore what these approaches would look like when applied consistently in one's leadership style and infused throughout a school community. School administrators need to be aware of existing legal protections and work to create an environment where homophobia and transphobia are not tolerated and all student identities and family structures are included and valued (Meyer, 2006; Meyer, 2008b).

These interventions are aimed at preventing more students and families from experiencing the same hostility and exclusion other queer youth and families have experienced. By challenging discriminatory and damaging policies and practices in the courts, these queer youth have made substantial contributions to creating more positive and inclusive learning environments in their schools. These youth are following in the footsteps of the trailblazers who came out before them and started demanding recognition in their school communities. Together, these activists have helped lead the way for improved social equality for gay, lesbian, bisexual, transgender, intersex, and queer individuals, and families. 


\section{NOTES}

1. For more detailed analysis on this case and how schools can apply the lessons learned from this decision, please see an earlier article by the author (Meyer, 2007).

2. Although research was done to identify cases in other countries, as of January 2008, no cases that had been brought against schools by queer youth were found.

3. Minnesota (1993); Rhode Island (1995, 2001); New Mexico (2003); California (1992, 2003); District of Columbia (1997, 2005); Illinois (2005); Maine (2005); Hawaii (1991, 2005, 2006); New Jersey (1992, 2006); Washington (2006); Iowa (2007); Oregon (2007); Vermont (1992, 2007); Colorado (2007); Wisconsin (1982); Massachusetts (1989); Connecticut (1991); New Hampshire (1997); Nevada (1999); Maryland (2001); New York (2002)

4. California, Connecticut, Maine, Massachusetts, Minnesota, New Jersey, Vermont, Washington, and Wisconsin

5. Alabama, Arizona, Mississippi, Oklahoma, South Carolina, Texas, and Utah

\section{REFERENCES}

American Civil Liberties Union (ACLU). (2007). LGBT and AIDS annual update. New York: American Civil Liberties Union.

American Civil Liberties Union (ACLU). (2004). Settlement fact sheet: Flores v. Morgan Hill Unified School District. Retrieved March 28, 2006, from www.aclu.org

American Civil Liberties Union-New Jersey. (2007). Victory for gay and other students who face harassment. Retrieved October 10, 2007, from http://www.aclunj.org/pressroom/victoryforgayandotherstude.htm

ACLU and Los Angeles School District settle anti-gay harassment case. (2005, June 29). Retrieved March 22, 2006, from www.aclu.org

Bagby, D. (2006). Ga. school's students face new hurdle for gay-straight club. Retrieved January 3, 2008, from http://www.southernvoice.com/thelatest/ thelatest. cfm?blogid $=8671$

Barnes, L. (2006, April 17). Gay teens' ordeal. News24.com.

Bochenek, M., \& Brown, A. (2001). Hatred in the hallways: Violence and discrimination against lesbian, gay, bisexual, and transgender students in U. S. schools (2001). New York: Human Rights Watch.

Boyd County High School Gay Straight Alliance v. Board of Education of Boyd County, Ky., 258 F. Supp. 2d 667 (E. D. KY, 2003).

Buchanan, W. (2006, April 1). Bills nationwide address gays in schools. San Francisco Chronicle. Retrieved April 12, 2006, from www.sfgate.com

Buckel, D. (2000). Legal perspective on ensuring a safe and nondiscriminatory school environment for lesbian, gay, bisexual, and transgender students. Education \& Urban Society, 32(3), 390-398.

California Safe Schools Coalition. (2004). Consequences of harassment based on actual or perceived sexual orientation and gender non-conformity and steps for making schools safer. Davis, CA: University of California.

Caudillo v. Lubbock, 311 F. Supp. 2d 550, (N. D. TX, Lubbock Division, 2004).

Cloud, J. (2005, May). The battle over gay teens. Time, Retrieved October 5, 2005, from www.time.com

D'Augelli, A. (2002) Mental health problems among lesbian, gay, and bisexual youths ages 14 21. Clinical Child Psychology and Psychiatry, 7, 433-456.

D'Augelli, A., \& Hershberger, S. (1993). Lesbian, gay, and bisexual youth in community settings: Personal challenges and mental health problems. American Journal of Community Psychology, 21, 421-448.

Davis v. Monroe County Board of Education, 526 U. S. 629 (1999).

Dias, J. (2008). Jer's Vision.org. Retrieved November 8, 2008, from www.jersvision. org

Dignan, J. (2004, January 8). Important victory for gay students. Gaycitynews. corn. Retrieved October 15, 2007, from http://www.gaycitynews.com/site/ index. cfm?newsid=17008546\&BRD $=2729 \& \mathrm{PAG}=461 \& \mathrm{dept} \mathrm{id}=568864 \& \mathrm{th}=8$

Dokladalova, J. (2007, January 18). GSA activist: "Diversity advocacy club" is not enough. Retrieved September 13, 2007, from $\underline{\text { http://www.tobe.ca/tobe/dialog }}$ printarticle .jsp?sid $=58651685114379275276024906131 \& \mathrm{ctid}=1000006 \& \mathrm{cnid}=1000926$ 
Doe v. Bellefonte Area School District, U. S. App. LEXIS 16207 (3rd Cir, 2004).

Doe v. Yunits and Brockton Sch. Comm., No. 2000-J-638 (Mass. App. 2000).

Dorais, M., \& LaJeunesse, S. (2004). Dead boys can't dance: Sexual orientation, masculinity, and suicide. Montreal: McGill-Queen's University Press.

Egan v. Canada (2 S.C.R. 513 1995).

Eisemann, V. (2000). Protecting kids in the hall: Using Title IX to stop studenton-student anti-gay harassment. Berkeley Women's Law Journal, 15(36), 125160.

Elze, D. (2003). Gay, lesbian and bisexual youths' perceptions of their high school environments and comfort in school. Children \& Schools, 25(4), 225239.

Fedders, B. (2006). Coming out for kids: Recognizing, respecting, and representing LGBTQ youth. Nevada Law Journal, 6, 774-804.

Fischer, S., \& Kosciw, J. (2006, April). The importance of gay-straight alliances: Social support and associations with teacher and staff response to homophobia. Paper presented at the Annual Meeting of the American Educational Research Association, San Francisco, CA.

Fisher, J. (1999). Reaching out. A report on lesbian, gay, and bisexual youth issues in Canada. Retrieved June 1, 2005, from www.egale.ca

Flores v. Morgan Hill, 324 F. 3d 1130 (9th Cir, 2003).

Forrest, S. (2000). Difficult loves: Learning about sexuality and homophobia in schools. In M. Cole (Ed.), Education, equality, and human rights: Issues of gender, 'race, ' sexuality, special needs and social class (pp. 99-117). New York: Routledge-Falmer Press.

Fricke v. Lynch, 491 F. Supp. 381 (RI, 1980).

Garcia-Alonso, P. (2004). From surviving to thriving: An investigation of the utility of support groups designed to address the special needs of sexual minority youth in public schools. Unpublished Doctoral dissertation, Loyola University, Chicago, IL.

Goodenow, C., Szalacha, L., \& Westhimer, K. (2006). School support groups, other school factors, and the safety of sexual minority adolescents. Psychology in the Schools, 43(5), 573-589.

Goss v. Lopez, 419 U. S. 565 1975).

Grace, A., \& Wells, K. (2005). The Marc Hall prom predicament: Queer individual rights v. institutional church rights in Canadian public education. Canadian Journal of Education, 28(3), 237-270.

Greytak, E., \& Kosciw, J. (2008). Leadership for school safety: The principal's perspective on school climate for lesbian, gay, bisexual, and transgender students and families. Paper presented at the Annual Meeting of the American Educational Research Association, New York, NY.

Griffin, P., Lee, C., Waugh, G., \& Beyer, C. (2004). Describing roles that gay-straight alliances play in schools: From individual support to school change. Journal of Gay \& Lesbian Issues in

Education, 1(3), 7-22.

Hall v. Durham Catholic District School Board (ON S.C. 2005).

Harris Interactive and GLSEN (2005). From teasing to torment: School climate in America, a survey of students and teachers. New York: Gay, Lesbian, and Straight Education Network.

Henkle v. Gregory, 150 F. Supp. 2d 1067 (Nev. Dist. 2001).

Illingworth, P., \& Murphy, T. (2004). In our best interest: Meeting moral duties to lesbian, gay, and bisexual adolescent students. Journal of Social Philosophy, 35(2), 198-210.

Janofsky, M. (2005, June 9). Gay rights battlefields spread to public schools. The New York Times. Retrieved June 9, 2005, from www.nytimes.com.

Kosciw, J. (2004). The 2003 national school climate survey: The school-related experiences of our nation's lesbian, gay, bisexual and transgender youth. New York: Gay, Lesbian, and Straight Education Network.

Kosciw, J., \& Diaz, E. (2006). 2005 National school climate survey. New York: Gay, Lesbian, and Straight Education Network.

Kosciw, J., Diaz, E., \& Gretytak, E. (2008). 2007 National school climate survey: The experiences of lesbian, gay bisexual, and transgender youth in our nation's schools. New York: Gay, Lesbian, and Straight Education Network.

L.W. v. Toms River Regional Schools Board of Education, A-111-05. (New Jersey Supreme Court 189 N.J. 381, 915 A.2d 535 2007). 
Lake City High School Clubs. (2008). Retrieved November 9, 2008, from http://www.cdaschools.org/lchs/activities/clubs/index.htm

Lambda Legal. (2001). Summary of the policy changes adopted as a result of the settlement in Henkle v. Gregory. New York: Lambda Legal. Retrieved September 5, 2006, from www.lambdalegal.org.

Lawrence v. Texas, 2003539 U.S. 558 (2003).

Leonard, A. (2004). Unusual gay student loss. Retrieved October 15, 2007, from http:// www.gaycitynews.com/site/index.cfm?newsid $=17005271 \& \mathrm{BRD}=2729 \& \mathrm{PAG}=461$ \&deptid $=568864 \& \mathrm{ffl}=8$.

Lipkin, A. (1999). Understanding homosexuality, changing schools. Boulder, CO: Westview Press.

Lock, J. (2002). Violence and sexual minority youth. Journal of School Violence, 1(3), 77-89.

Lugg, C. (2003). Sissies, faggots, lezzies, and dykes: Gender, sexual orientation, and a new politics of education? Educational Administration Quarterly, 39(1), 95-134.

Lugg, C. (2006). Thinking about sodomy: Public schools, legal panopticons, and queers. Educational Policy, 20(1), 35-58.

Lyttle, S. (2006, April 11). Schools reject gay-straight club. The Charlotte Observer (NC). Retrieved April 18, 2006, from Lexis-Nexis databases.

Macgillivray, I. K. (2004). Gay rights and school policy: A case study in community factors that facilitate or impede educational change. International Journal of Qualitative Studies in Education, 17(3), 347-370.

Macgillivray, I. (2005). Shaping democratic identities and building citizenship skills through student activism: Mexico's first gay-straight alliance. Journal of Educational Excellence and Equity, 38, 320-330.

Macgillivray, I. (2007). Gay-straight alliances: A bandbook for students, educators, and parents. Binghamton, NY: Harrington Park Press.

Mackinnon, J. (2002). Excerpts from the judgment of MacKinnon, J. in the Marc Hall case [Electronic Version]. Egale Canada. Retrieved October 1, 2003, from www.egale.ca

Madkor, R. (2006, January 14). Speakers spar over school club. Spokane Spokesman-Review. Retrieved February 7, 2006 from Lexis-Nexis databases.

Martino, W., \& Pallotta-Chiarolli, M. (2003). So what's a boy? Addressing issues of masculinity and schooling. Buckingham, UK: Open University Press.

Mayo, C. (2004). Disputing the subject of sex: Sexuality and public school controversies. Lanham, MD: Rowman \& Littlefield.

McLaughlin v. Pulaski County Special School District, 296 F. Supp. 2d 960 (E. D. AR, W. D., 2003).

Meyer, E. (2006). Gendered harassment in North America: School-based interventions for reducing homophobia and heterosexism. In C. Mitchell \& F. Leach (Eds.), Combating gender violence in and around schools (pp. 43-50). Stoke-on-Trent, UK: Trentham Books.

Meyer, E. (2007). Lessons from Jubran: Reducing school board liability in cases of peer harassment [Electronic Version]. Proceedings of the 17th Annual Conference of the Canadian Association for the Practical Study of Law in Education, Vol. 1, 561-576.

Meyer, E. (2008a). A feminist reframing of bullying and harassment: Transforming schools through critical pedagogy. McGill Journal of Education, 43(1), 33-48.

Meyer, E. (2008b). Gendered harassment in secondary schools: Understanding teachers' (non)interventions. Gender \& Education, 20(6), 555-572.

Mills, M. (2006). Issues of masculinity and violence in Australian schools. In F. Leach \& C. Mitchell (Eds.), Combating gender violence in and around schools (pp. 163-170). Stokeon-Trent, UK: Trentham.

Montgomery v. Independent School District no. 709 109 F. Supp.2d 1081 (D. Minn. 2000).

Moran, J. (2006, June 16). Jeremy Dias creates scholarship with rights settlement. Capital Xtra (Ottawa, Canada).

Nabozny v. Podlesny, 92 F. 3d 446 (7th Cir, 1996).

National Gay and Lesbian Task Force. (2007, September 17). State Nondiscrimination Laws in the U.S.

Retrieved January 3, 2008, from http://www.thetaskforce.org/

downloads/reports/issue_maps/non_discrimination_09_07.pdf 
National Coalition to Support Sexuality Education (NCSSE). (2003). Gay straight alliance (gsa) allowed at Texas school. Retrieved January 3, 2008, from http://www.ncsse.org/mandates/TX.html

Nguon v. Wolf No. 05-868 (C.D. Cal. Sept. 25, 2007).

OutThere, New Zealand AIDS Foundation, \& Rainbow Youth. (2004). Safety in our schools. Wellington, New Zealand: Author.

Perrotti, J., \& Westheimer, K. (2001) When the drama club is not enough: Lessons from the Safe Schools Program for Gay and Lesbian Students. Boston: Beacon Press.

Phoenix, A., Frosh, S., \& Pattman, R. (2003). Producing contradictory masculine subject positions: Narratives of threat, homophobia and bullying in 11-14 year old boys. Journal of Social Issues, 59(1), 179-195.

Ravitz, J. (2004a, December 2) To dance, gay teen needs OK of parents. The Salt

$L$ ake Tribune. Retrieved December 13, 2005, from Lexis-Nexis databases. Ravitz, J.

(2004b, December 22) Gays win skirmish over dates for dance. The Salt

$L$ ake Tribune. Retrieved January 16, 2005, from Lexis-Nexis databases.

Ray v. Antioch Unified School District (107 F. Supp. 2d 1165 (N.D. Cal. 2000). Sampson,

P. (2000). Will participation in a gay/straight alliance mitigate risk behav-

ior in gay and lesbian youth? Unpublished manuscript. Salem, MA: Salem State

College.

Savin-Williams, R. (2001). Suicide attempts among sexual-minority youths: Population and measurement issues. Journal of Counselling and Clinical Psychology, 69, 983-991.

School District No. 44 (North Vancouver) v. Jubran, 2005 BCCA 201 (BCSC 6 2005).

Smith, G., \& Smith, D., Eds. (1998). The ideology of "fag": The school experience of gay students. Sociological Quarterly, 39(2), 309-335.

Stader, D. (2007). Law and ethics in educational leadership. Upper Saddle River, NJ: Pearson Education.

Stader, D., \& Graca, T. (2006, April 7-11, 2006). Sexual minority youth and school culture: A study of educational leadership candidates' perceptions of Dallas-Fort Worth area secondary schools. Paper presented at the annual meeting of the American Educational Research Association, San Francisco, CA.

Stader, D., \& Meyer, E. (2006, October 12). Sexual minority youth and the culture wars: Out of the closet and drafted into battle. Paper presented at the Annual Meeting of the Education Law Association. Paradise Island, Bahamas.

Staff. (1997, April 14). Back to school for Aussie teen. Retrieved October 15, 2007, from http://www.planetout.com/news/article.html?1997/04/14/2

Staff. (2006). Gay, lesbian and straight education network praises North Carolina student's courage forming GS A. Retrieved January 3, 2008, from http:/ / www.gaywired.com/article.cfm?section=66\&id=11465

Staff. (2007, October 3). Judge rules against lesbian in high school outing case. Retrieved January 3 , 2008, from http://www.advocate.com/news detail_ektid49529.asp

Straights and Gays for Equity v. Osseo Area Schools (Civ. No. 05-21000 (JNE/FLN), (Mn 2006).

Szlacha, L. (2001). The sexual diversity climate of Massachusetts' secondary schools and the success of the Safe Schools Program for Gay and Lesbian Students. Unpublished doctoral dissertation, Harvard University, Cambridge, MA.

Szlacha, L. (2003). Safer sexual diversity climates: Lessons learned from an evaluation of Massachusetts Safe Schools Program for Gay and Lesbian Students. American Journal of Education, 110(1), 58-88.

Terminiello v. Chicago, 337 U.S. 1, (1949)

Tinker v. Des Moines School District, 393 U.S. 503 (1969)

Theno v. Tonganoxie Unified School Dist. No. 464 (2005 WL 3434016, (D. Kan. 2005).

Thompson, S., \& Johnson, L. (2003). Risk factors of gay, lesbian, and bisexual adolescents: Review of empirical literature and practice implications. Journal of Human Behavior in the Social Environment, 8(2-3), 111-128.

Thonemann, A. (1999). Enabling and disabling conditions for teaching against homophobia. Paper presented at the Australian Association for Research in Education Conference, Melbourne, Australia. 
Timmerman, G. (2003). Sexual harassment of adolescents perpetrated by teachers and peers: An exploration of the dynamics of power, culture, and gender in secondary schools. Sex Roles, 48(5-6), 231-244.

Toomer-Cook, J. (2007, July 28). Utah ranks 35th in gay-straight clubs. Desert News. Warwick, I., Goodrich, R., Aggleton, P., \& Chase, E. (2006). Homophobic bullying and schools—Responding to the challenge. Youth \& Policy, 91, 59.

Weiler, E. (2003). Making school safe for sexual minority students. Principal Leadership, 4(4), 10-13.

White County High School Peers in Diverse Education v. White County School District, Civil Action No. 2:06-CV-29-WCO N. D. Georgia, Gainesville Division, (2006).

Williams, T., Connolly, J., Pepler, D., \& Craig, W. (2003). Questioning and sexual minority adolescents: High school experiences of bullying, sexual harassment and physical abuse. Canadian Journal of Community Mental Health, 22(2), 47-58.

\section{CONTRIBUTORS}

Elizabeth J. Meyer, Ph.D., is a former high school teacher and a course lecturer at McGill University. She is the author of Gender, Bullying and Harassment: Strategies to End Sexism and Homophobia in Schools. Information about her current research is available at: http://lizjmeyer.googlepages.com.

David L. Stader, Associate Professor, holds the Ed.D. in Educational Leadership from St. Louis University, St. Louis, MO. His primary research interest considers how changes in law and society influence the decision-making of campus leaders. 